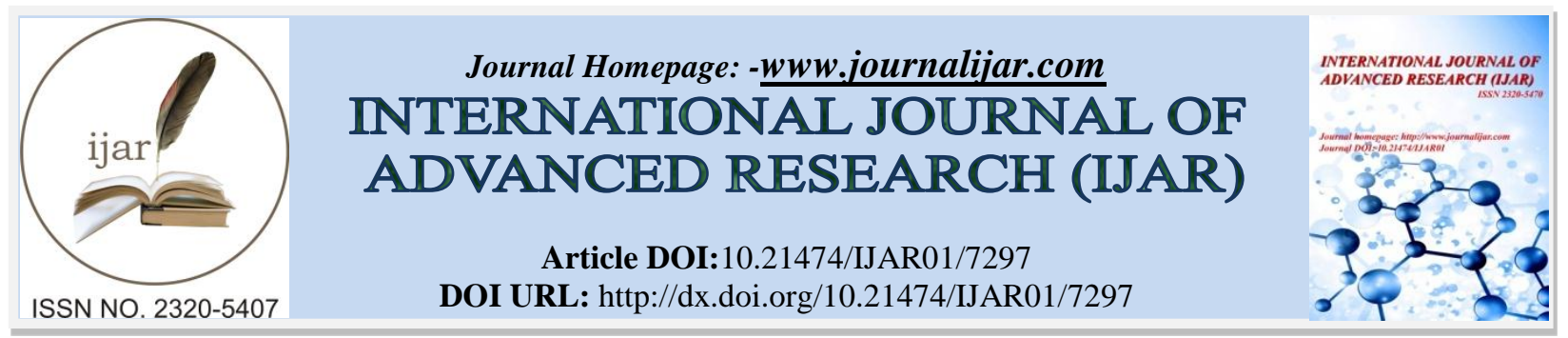

RESEARCH ARTICLE

\title{
A COMPARATIVE STUDY ON THE QUALITY OF LIFE OF AMONG WORKING WOMEN OF GOVERNMENT SECTOR AND PRIVATE SECTOR.
}

\section{Simran Kapoor ${ }^{1}$ and Dr. Divya Sanghi ${ }^{2}$.}

1. Department of Nutrition and Dietetics, Faculty of Applied Sciences, Manav Rachna International Institute of Research and Studies, Faridabad.

2. Associate Professor, Department of Nutrition and Dietetics, Faculty of Applied Sciences, Manav Rachna International Institute of Research and Studies, Faridabad.

\section{Manuscript Info}

Manuscript History

Received: 16 April 2018

Final Accepted: 18 May 2018

Published: June 2018

Keywords:-

Quality Of Life, Private Sector And

Government Sector.

\section{Abstract}

Introduction: Today's career women are continually challenged by the demands of full-time work and when the day is done at the office, they carry more of the responsibilities and commitments to home. Women are growing more ambitious as they become key players in the world of work, contributing to major company successes. Due to work pressure at working place and home, kind of work, working hours and etc (government sector and private sector) may be affect their Quality of life.

Aim and Objective: With the above background, present study was conducted with the aim to assess the difference in quality of life of females working in public and private sector.

Methodology: Present study recruited 50 working women from Delhi NCR belonging to government and private sector of 25-35 years of age. A pretested questionnaire was used to collect the data from study subjects. It included demographic (age, marital status, education and family income) and anthropometric (Height, weight and BMI) data. Quality of life of subjects was assessed by using WHO Quality of life questionnaire.

Results: Both group was age matched $(\mathrm{p}=0.11)$. The Government sector group were having more post graduated $(92 \%)$ as compare to private sector $(60 \%)$ and both the group didn't contain any subject who were having only senior secondary degree. Both groups were having similar type of family income structure most of the subjects (80\%) were earning $>50,000$. The dietary pattern of both group was similar as almost half of population were consuming non-vegetarian diet. Scores of all four domains of quality of life scale were not statistically different between both groups. But when the subjects were distributed on the basis of cut off values the environment health domain came to be significantly different between both the groups. As in government sector, $72 \%$ subjects were having good quality of life whereas in private sector only $44 \%$ subject were having good quality of life and it was statistically significant ( $\mathrm{p}$ value- 0.04 ).

Conclusion: Present study concluded that out of four domains of quality of life, only environment health domain was better in 
government sector in comparison to private sector inspite of similarity in all the studied variables.

Copy Right, IJAR, 2018,. All rights reserved.

\section{Introduction:-}

Quality of life (QOL) is a broad multidimensional concept that usually includes subjective evaluations of both positive and negative aspects of life. What makes it challenging to measure is that, although the term "quality of life" has meaning for nearly everyone and every academic discipline, individuals and groups can define it differently. Although health is one of the important domains of overall quality of life, there are other domains as well-for instance, jobs, housing, schools, the neighbourhood. Aspects of culture, values, and spirituality are also key domains of overall quality of life that add to the complexity of its measurement. Nevertheless, researchers have developed useful techniques that have helped to conceptualize and measure these multiple domains and how they relate to each other ${ }^{1}$.

The social structure was not developed properly in the ancient time. So, the less importance has been given to the quality of living standard in those days. But this is the age of competition and physical development. Thus, more attention has been given to the development of quality of life. Whatever the progress has been made in the name of development, the main goal is to provide the peace, pleasure and satisfaction to the human beings. The education is a light of knowledge which leads the people on the right path. Education is also the source of skills and capacities. It helps to maintain the quality of living standard. Every couple should be active to provide the quality education to the children. Quality education becomes fruitful in future for their children to generate the sound income sources. The income generation occupation with the high salary helps to maintain the quality of living standard. The quality of life of the people is deeply related with the socio-cultural aspects of the society. The quality of life plays a vital role to bring the change in social and cultural development in the entire nation. The quality of life has made an incomparable contribution in the development of economic sector. The economic development is the backbone of the development of any nation ${ }^{3-6}$.

Today's career women are continually challenged by the demands of full-time work and when the day is done at the office, they carry more of the responsibilities and commitments to home. Women are growing more ambitious as they become key players in the world of work, contributing to major company successes. Due to work pressure at working place and home, kind of work, working hours and etc (government sector and private sector) may be affect their Quality of life. With the above background the above study was formulated to analysed the difference of quality of life in females belonging to government and private sector.

\section{Designs And Methods:-}

The present study was conducted in Delhi-NCR to compare quality of life among working women of government and private sector. Data was collected by purposive sampling and total 50 sample was taken from either group among the age of 25-35 years female. Data collection started in January 2017 and completed by March 2017.

Sample was recruited as per inclusion and exclusion criteria. The Inclusion criteria of the study was 1) subject aged between 25-35 years, 2) only females 3) and subjects willing to participate. The exclusion criteria were males and candidates not willing to participate.

A pretested questionnaire was used to collect demographic profile and anthropometric profile. Quality of life was measured by using WHO - 'QUALITY OF LIFE - BREF' standardized Questionnaire. Statistically analysis was done by using software SPSS vs. 20.

\section{Result And Discussion:-}

Present study enrolled total 50 females of either group from different location of Delhi-NCR. Out of 50 females, $50 \%$ were working in government sector $(n=25)$ and $50 \%$ were private sector $(n=25)$ with the age of group of $25-35$ years. 
Table 1:-Description data of study subjects

\begin{tabular}{|l|l|c|c|}
\hline DEMOGRAPHIC DATA & $\begin{array}{l}\text { GOVERNMENT SECTOR } \\
(\mathbf{n = 2 5})\end{array}$ & $\begin{array}{l}\text { PRIVATE SECTOR } \\
(\mathbf{n = 2 5})\end{array}$ & p-value \\
\hline AGE & $29.88 \pm 2.65$ & $31.24 \pm 3.21$ & 0.11 \\
\hline $\begin{array}{l}\text { MARITAL STATUS n (\%) } \\
\text { Single: Married: Divorced }\end{array}$ & $8(32): 16(64): 1(4)$ & $6(24): 19(76): 0(0)$ & 0.46 \\
\hline $\begin{array}{l}\text { EDUCATION } \\
\begin{array}{l}\text { Senior Secondary: Graduated: Post } \\
\text { graduated }\end{array}\end{array}$ & $0(0): 2(8): 23(92)$ & $0(0): 10(40): 15(60)$ & 0.01 \\
\hline $\begin{array}{l}\text { FAMILY INCOME } \\
>50,000: \text { 40,000-30,000: }<20,000\end{array}$ & $20(80): 5(20): 0(0)$ & $19(76): 5(20): 1(4)$ & 0.60 \\
\hline FOOD HABITS & $7(28): 10(40): 8(32)$ & $9(36): 14(56): 2(8)$ & 0.11 \\
\hline $\begin{array}{l}\text { Vegetarian: Non-vegetarian: Ova- } \\
\text { vegetarian }\end{array}$ & & \\
\hline
\end{tabular}

Demographic data of study subjects (table 1) depicted that the mean age of Government sector was $29.88 \pm 2.65$ and Private sector was 31.24 \pm 3.21 which was statistically insignificant $(\mathrm{p}=0.11)$. Marital status, family income and food habit were also not significantly different between both the groups $(\mathrm{p}>0.05)$.

The education status of both group was significantly different $(\mathrm{p}=0.01)$. In government sector $92 \%$ were post graduated and $8 \%$ were graduated whereas only $60 \%$ were post graduated and $40 \%$ were graduated in private sector, and both the group didn't contain any subject who were senior secondary.

Table 2:-Anthropometric measurements of both groups

\begin{tabular}{|l|c|c|c|}
\hline $\begin{array}{l}\text { Anthropometric } \\
\text { measurements }\end{array}$ & $\begin{array}{c}\text { Government Sector } \\
(\mathbf{n = 2 5})\end{array}$ & $\begin{array}{c}\text { Private Sector } \\
(\mathbf{n = 2 5})\end{array}$ & p-value \\
\hline Height $(\mathrm{cm})$ & $166.70 \pm 8.42$ & $161.77 \pm 5.51$ & 0.020 \\
\hline Weight $(\mathrm{Kg})$ & $65.92 \pm 7.26$ & $66.36 \pm 6.78$ & 0.826 \\
\hline BMI & $23.89 \pm 2.78$ & $25.57 \pm 3.13$ & 0.051 \\
\hline
\end{tabular}

The anthropometric measurement of both groups (table 2) shown that the mean height was $166.70 \pm 8.42$ and $161.77 \pm 5.51$ in government and private sector respectively and this was statistically significant $(\mathrm{p}=0.02)$. The mean weight was $65.92 \pm 7.26$ and $66.36 \pm 6.78$ in government and private sector and this difference was also not statistical significant. The BMI was also insignificantly different between both group $(\mathrm{p}=0.05)$.

Table 3:-Quality of life score of both groups

\begin{tabular}{|l|l|l|l|}
\hline \multicolumn{1}{|c|}{ Quality of Life domains } & \multicolumn{1}{|c|}{$\begin{array}{c}\text { Government Sector } \\
(\mathbf{n = 2 5})\end{array}$} & $\begin{array}{c}\text { Private Sector } \\
(\mathbf{n = 2 5})\end{array}$ & p-value \\
\hline Physical Health (Domain 1) & $48.16 \pm 10.61$ & $51.04 \pm 9.67$ & 0.32 \\
\hline Psychological Health (Domain 2) & $48.04 \pm 18.31$ & $55.56 \pm 14.69$ & 0.12 \\
\hline Social Health (Domain 3) & $58.67 \pm 18.86$ & $59.08 \pm 20.01$ & 0.95 \\
\hline Environmental Health (Domain 4) & $49.32 \pm 17.78$ & $58.87 \pm 19.32$ & 0.07 \\
\hline
\end{tabular}

WHO "Quality of Life" contains four domain donates an individual's perception of quality of life. The mean score of domain 1, 2,3 and 4 of government sector was is $48.16 \pm 10.61,48.04 \pm 18.31,58.67 \pm 18.86$ and $49.32 \pm 17.78$ respectively. The mean score of domain 1,2,3 and 4 of private sector was $51.04 \pm 9.67,55.56 \pm 14.69,59.08 \pm 20.01$ and 58.87 \pm 19.32 respectively. All the four domains were not significantly different in both groups.

Table 4:-Distribution of study subjects according to Quality of life cutoff

\begin{tabular}{|l|l|l|l|l|}
\hline \multicolumn{1}{|c|}{ Quality of Life domains } & \multicolumn{2}{c|}{$\begin{array}{c}\text { Government Sector } \\
(\mathbf{n = 2 5})\end{array}$} \\
\hline Physical Health & $\mathbf{N}$ & $\mathbf{\%}$ & $\mathbf{N}$ & \% \\
\hline POOR QOL & 12 & 48 & 12 & 48 \\
\hline GOOD QOL & 13 & 52 & 13 & 52 \\
\hline Psychological Health & & & & \\
\hline POOR QOL & 11 & 44 & 9 & 36 \\
\hline
\end{tabular}




\begin{tabular}{|l|l|l|l|l|}
\hline GOOD QOL & 14 & 56 & 16 & 64 \\
\hline Social Health & & & & \\
\hline POOR QOL & 17 & 68 & 15 & 60 \\
\hline GOOD QOL & 8 & 32 & 10 & 40 \\
\hline Environmental Health & & & & \\
\hline POOR QOL & 7 & 28 & 14 & 56 \\
\hline GOOD QOL & 18 & 72 & 11 & 44 \\
\hline
\end{tabular}

p-value was derived by using student T-test.

Distribution of study subjects in both groups according to cutoff values of each domain of quality of life scales were depicted in Table 4. Out of all four domains, only environmental health domain came out to be significantly different between both the groups. In government sector $72 \%$ subjects were having good quality of life whereas in private sector only $44 \%$ subject were having good quality of life in regards to environmental domain, and it was statistically significant $(\mathrm{p}=004)$. There was no significant difference of physical domains in both the groups $(\mathrm{p}=1.00)$. In psychological domain, $64 \%$ subjects of private sector and $56 \%$ subjects of government sector were having good quality of life and this was statistically not significant. In regards to social domain only $40 \%$ and $32 \%$ subjects of private and government sector respectively were having good quality of life.

\section{Bibliography:-}

1. The WHOQOL Group. The World Health Organization Quality of Life Assessment (WHOQOL). Development and psychometric properties. Soc Sci Med 1998;46:1569-1585.

2. Preamble to the Constitution of the World Health Organization as adopted by the International Health Conference, New York, 19-22 June, 1946; signed on 22 July 1946 by the representatives of 61 States (Official Records of the World Health Organization, no 2, p. 100) and entered into force on 7 April 1948.

3. Centers for Disease Control and Prevention. Measuring healthy days: Population assessment of health-related quality of life. Centers for Disease Control and Prevention, Atlanta, Georgia 2000.

4. Gandek B, Sinclair SJ, KosinskiM, Ware JE.(2004) psychometric evaluation of the SF-36 health survey in Medicare managed care. Health Care Financ Rev;25(4):5-25.

5. McHorney CA.(1999) Health status assessment method for adults: past accomplishments and future direction. Annual Rev Public Health; 20:309-35.

6. Selim AJ, Rogers W, Fleishman JA, Qian SX, Fincke BG, Rothendler JA, Kazis LE.(2009) updated U.S. population standard for the Veterans RAND 12- item Health Survey(VR-12). Quad Life Res; 18(1):43-52.

7. http://www.who.int/substance_abuse/research_tools/en/english_whoqol.pdf. 